\title{
First report of Lecanodiaspis dendrobii Douglas, 1892 (Hemiptera: Lecanodiaspididae) and the associated parasitoid Cephaleta sp. (Hymenoptera: Pteromalidae) in Brazil
}

\author{
A. L. Marsaro Júniora*, A. L. B. G. Peronti ${ }^{b}$, V. A. Costac, \\ E. G. F. Morais ${ }^{d}$ and P. R. V. S. Pereira ${ }^{a}$ \\ ${ }^{a}$ Laboratório de Entomologia, Embrapa Trigo, BR 285, km 294, CP 451, CEP 99001-970, Passo Fundo, RS, Brazil \\ ${ }^{\text {b} D e p a r t a m e n t o ~ d e ~ F i t o s s a n i d a d e, ~ F a c u l d a d e ~ d e ~ C i e ̂ n c i a s ~ A g r a ́ r i a s ~ e ~ V e t e r i n a ́ r i a s ~-~ F C A V, ~ U n i v e r s i d a d e ~ E s t a d u a l ~ P a u l i s t a ~}$ \\ "Júlio de Mesquita Filho" - UNESP, Rod. Prof. Paulo Donato Castellane, km 5, CEP 14884-900, Jaboticabal, SP, Brazil \\ ${ }^{c}$ Centro Experimental Central, Instituto Biológico, Rod. Heitor Penteado, km 3, CEP 13001-970, Campinas, SP, Brazil \\ ${ }^{d}$ Laboratório de Entomologia, Embrapa Roraima, BR 174, km 8, CP 133, CEP 69301-970, Boa Vista, RR, Brazil \\ *e-mail: alberto.marsaro@embrapa.br
}

Received: September 26, 2014 - Accepted: November 6, 2014 - Distributed: February 29, 2016

(With 8 figures)

\begin{abstract}
Lecanodiaspis dendrobii Douglas, 1892 (Hemiptera: Coccoidea: Lecanodiaspididae) and the associated parasitoid Cephaleta sp. (Hymenoptera: Pteromalidae) are reported for the first time in Brazil. Specimens of this scale insect were collected on branches and stems of Acacia mangium Willd., Leucaena leucocephala (Lam.) de Wit (Fabaceae), Morus nigra L. (Moraceae), Citrus reticulata Blanco (Rutaceae), Tectona grandis L. f. (Verbenaceae), Anacardium occidentale (Anacardiaceae), Annona squamosa L. and Xylopia aromatica (Lam.) Mart. (Annonaceae), in three municipalities of the Roraima state. All plants here mentioned are recorded for the first time as a host for $L$. dendrobii. Morphological characters of $L$. dendrobii and symptoms presented by the host plants infested by this pest are included in this work.

Keywords: pest of quarantine importance, Fabaceae, Moraceae, Rutaceae, Verbenaceae.

\section{Primeiro registro da cochonilha Lecanodiaspis dendrobii Douglas, 1892 (Hemiptera: Coccoidea: Lecanodiaspididae) e do parasitoide associado Cephaleta sp. (Hymenoptera: Pteromalidae) no Brasil}

\begin{abstract}
Resumo
Lecanodiaspis dendrobii Douglas, 1892 (Hemiptera: Coccoidea: Lecanodiaspididae) e o parasitoide associado Cephaleta sp. (Hymenoptera: Pteromalidae) são registrados pela primeira vez no Brasil. Exemplares dessa cochonilha foram coletados sobre ramos e fustes de Acacia mangium Willd., Leucaena leucocephala (Lam.) de Wit (Fabaceae), Morus nigra L. (Moraceae), Citrus reticulata Blanco (Rutaceae), Tectona grandis L.f. (Verbenaceae), Anacardium occidentale (Anacardiaceae), Annona squamosa L. e Xylopia aromatica (Lam.) Mart. (Annonaceae), em três municípios do Estado de Roraima. Todas as plantas aqui mencionadas são registradas pela primeira vez como hospedeiras de L. dendrobii. Caracteres morfológicos da cochonilha e sintomas das plantas hospedeiras infestadas por esta praga são incluídos neste trabalho.
\end{abstract}

Palavras-chave: praga de importância quarentenária, Fabaceae, Moraceae, Rutaceae, Verbenaceae.

\section{Introduction}

Lecanodiaspis dendrobii (Hemiptera: Coccoidea: Lecanodiaspididae) is a polyphagous scale insect that feeds on many plant species distributed in six botanic families: Euphorbiaceae, Fabaceae, Moraceae, Orchidaceae, Rutaceae and Verbenaceae (García et al., 2015).

Macroscopically the body of the adult female of L. dendrobii is purplish-brown, flattened, covered by a light brown test infused with secondary white wax; test with longitudinal mediodorsal carina intersected by transverse raised lines. Male test similar in texture and appearance, more elongate. Microscopically L. dendrobii is characterized by having 3 to 5 cribriform plates on each side of body; anterior and posterior spiracular setae present; posterior spiracular furrows divided; antennae 7- to 9-segmented; legs rudimentary (Howell and Kosztarab, 1972; Miller et al., 2014). 
Studies on the biology of this species have not been conducted yet and information about damages on their host plants are inexistent.

The lecanodiaspidid $L$. dendrobii was described by Douglas in 1892, collected on Dendrobium calceolaria (Orchidaceae) in Demerara, Republic of Guyana (Douglas, 1892). Later it was recorded in several places in Central and South America: Argentina (Buenos Aires, Cordoba, Corrientes, San Juan and Tucuman), Colombia, Guatemala, Honduras, Uruguay and Venezuela. Recently, it was also recorded in northern Mexico (Nearctic Region) (García et al., 2015). As a consequence of their presence in Mexico, this pest was already included on the list of pests of quarantine importance to the U.S. (Miller et al., 2014).

The state of Roraima is bordered by two countries where L. dendrobii has been reported, Republic of Guyana and Venezuela, thus their occurrence has been expected in Brazil.

The present paper aims to report $L$. dendrobii for the first time in Brazil, as well as its parasitoid, morphological characters of this scale insect, symptoms presented by the host plants infested by this pest and suggestions for its management are given.

\section{Material and Methods}

Samples suspected to contain specimens of Lecanodiaspis dendrobii were initially collected in Roraima State, Brazil, by the first author (A.L.M.J), on branches and stems of several host plants in the municipalities: Boa Vista, in a reforestation area on young and mature plants of Acacia mangium Willd. (Fabaceae) and on a young plant of Xylopia aromatica (Lam.) Mart. (Annonaceae), (N 030. $04.2^{\prime \prime}$, W 6049'45.8'), in December 2009; in young plants of Leucaena leucocephala (Lam.) de Wit (Fabaceae), (N 02'57'41.2”, W 6042'53.0”), in January 2010; on one mature plant of Morus nigra L. (Moraceae), (N 0245'27.5", W 6043'48.4"), in February 2010; and Cantá, on mature plants of Citrus reticulata Blanco (Rutaceae), (N 02 18'57.3”, W 60³5'15.8'), in March 2010. Posteriorly, the fourth author (E.G.F.M) collected samples on mature plants of Tectona grandis Lf (Verbenaceae) in the municipality of Alto Alegre, (N 0244'24.1’, W 61¹7'39.7’), in June 2011, on mature plants of Anacardium occidentale L. (Anacardiaceae) in the municipality of Cantá, $(\mathrm{N}$ 0243'24.4”, W 6040'37.5'), in March 2012, and on plants of Annona squamosa L. (Annonaceae), also in Cantá (N 2॰43'53.3”, W 60³8'14.9”'), in May 2014.

Part of the samples of the scale insect were stored in vials filled with $75 \%$ ethanol and the other part were placed in glass tubes, closed with cotton until the emergency of the parasitoids, and posteriorly stored in $100 \%$ ethanol. The scale insects and the hymenopterous parasitoid were identified respectively by the authors (A.L.B.G.P. and V.A.C.).

The lecanodiaspidids were mounted on microscopic slides following the methodology described by Gullan (1984) and identified according to morphological characteristics of the adult female as described by Howell and Kosztarab (1972) and Miller et al. (2014). The hymenopterous parasitoids were double-mounted on points and identified using Bouček and Heydon (1997) at the genus level and pertinent literature for species. The specimens of coccoids were deposited at the Universidade Federal de São Carlos, São Carlos, São Paulo, Brazil and the hymenopterous parasitoids at the "Coleção de Insetos Entomófagos Oscar Monte”, Instituto Biológico, Campinas, São Paulo, Brazil.

\section{Results}

All samples of lecanodiaspidids collected on A. mangium, L. leucocephala, M. nigra and $X$. aromatica, in Boa Vista; on A. occidentale, C. reticulata and A. squamosa, in Cantá; and T. grandis, in Alto Alegre; were identified as Lecanodiaspis dendrobii Douglas, 1892 (Hemiptera: Lecanodiaspididae) (Figure 1); and all these plants are recorded for the first time as host plants for $L$. dendrobii.

Based on material collected in Roraima, adult females (Figure 2) measure about 2.0-4.5 mm long and 1.5-3.5 mm wide. Eggs (Figure 3), and all instars of females and males (Figure 4) were found.

Mature plants when infested by L. dendrobii showed drying of apical branches (Figure 5), but when infestation occurred in young plants, injuries caused the death of the host (Figure 6). The honeydew excreted on the leaves, by this insect, favored the development of sooty mold (Figure 7), compromising plant photosynthesis and causing premature leaf drop.

The parasitoid associated with $L$. dendrobii was identified as Cephaleta sp. (Hymenoptera: Pteromalidae) (Figure 8) and it emerged from specimens collected on M. nigra in the municipality of Boa Vista.

\section{Discussion}

Lecanodiaspis dendrobii is the second species of the genus recorded in Brazil, previously only Lecanodiaspis rugosa Hempel, 1900 was known. The genus includes 54 species distributed in all zoogeographic regions except Antarctica, most restricted to Afrotropical and Australasian regions. For South America only seven of these species are known (García et al., 2015).

According Miller et al. (2014), L. dendrobii and Lecanodiaspis prosopidis (Maskell, 1895), distributed between South Mexico and North USA, may be synonyms. Lecanodiaspis dendrobii differs by having 2 long setae anterior of vulva (absent in L. prosopidis) (Howell and Kosztarab, 1972; Miller et al., 2014). In this case, due to great microscopic similarity between the two species, additional morphological and molecular studies may help to confirm this supposition.

Six years after the record of $L$. dendrobii in Brazil, in Boa Vista, it was found in rural areas of the two neighboring municipalities, Cantá and Alto Alegre (Figure 1), and on new host plants, showing a good adaptation of the species in the region. 


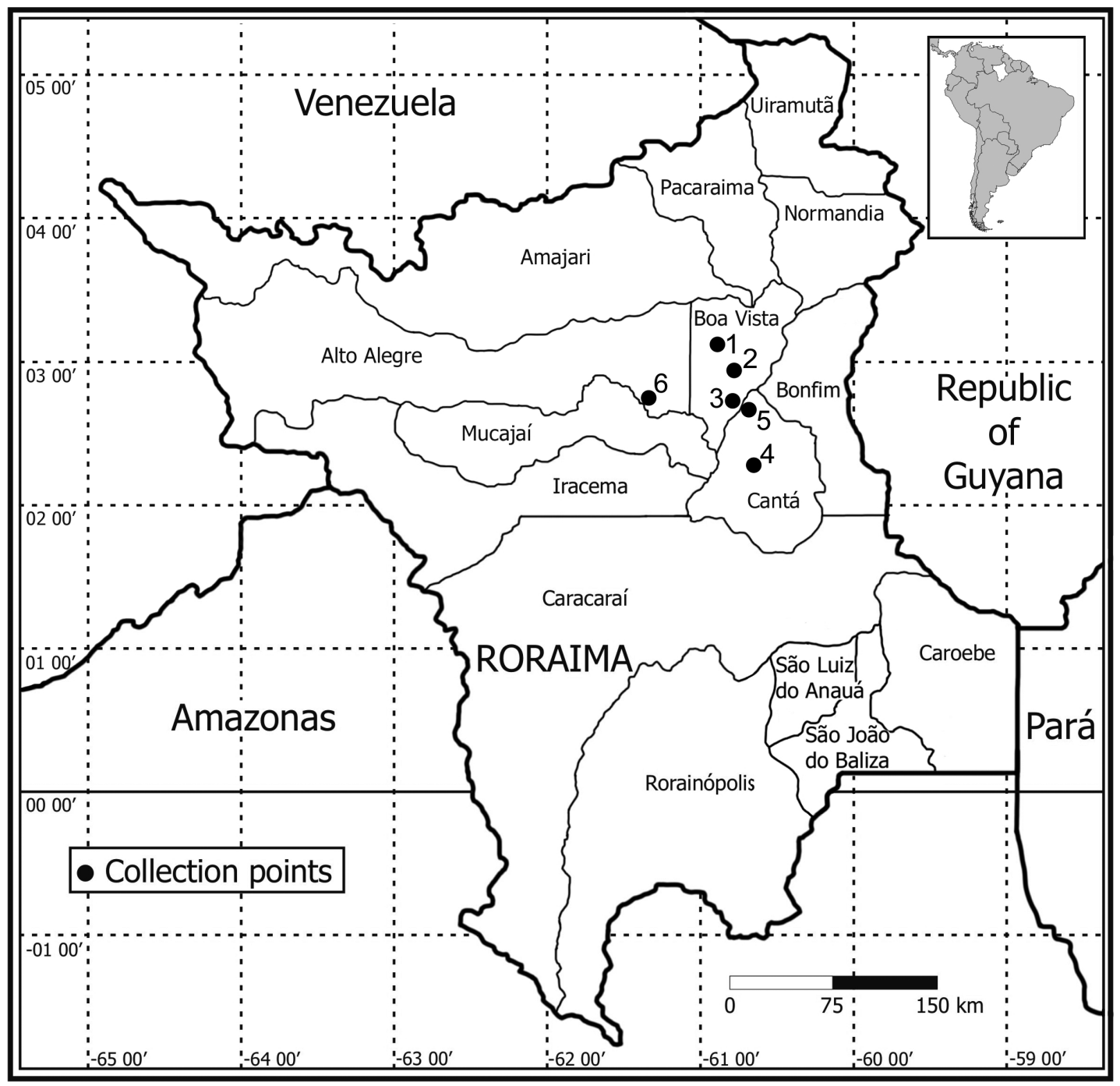

Figure 1. Map of the State of Roraima indicating the points in each municipality* and host plants where Lecanodiaspis dendrobii Douglas, 1892 was collected. ${ }^{* 1}$ Boa Vista, Acacia mangium and Xylopia aromatica; ${ }^{2}$ Boa Vista, Leucaena leucocephala; ${ }^{3} \mathrm{Boa}$ Vista, Morus nigra; ${ }^{4}$ Cantá, Citrus reticulata $;{ }^{5}$ Cantá, Anacardium occidentale and Annona squamosa; ${ }^{6}$ Alto Alegre, Tectona grandis.

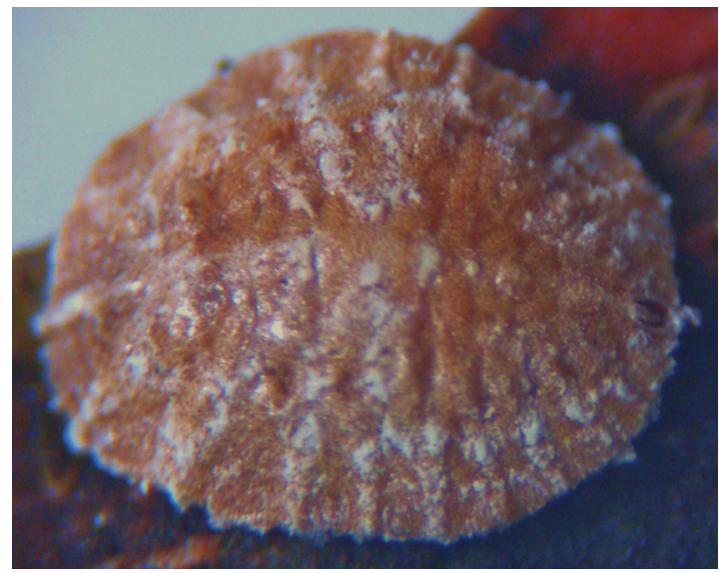

Figure 2. Adult female of L. dendrobii. Photo: Marsaro Júnior, A.L.

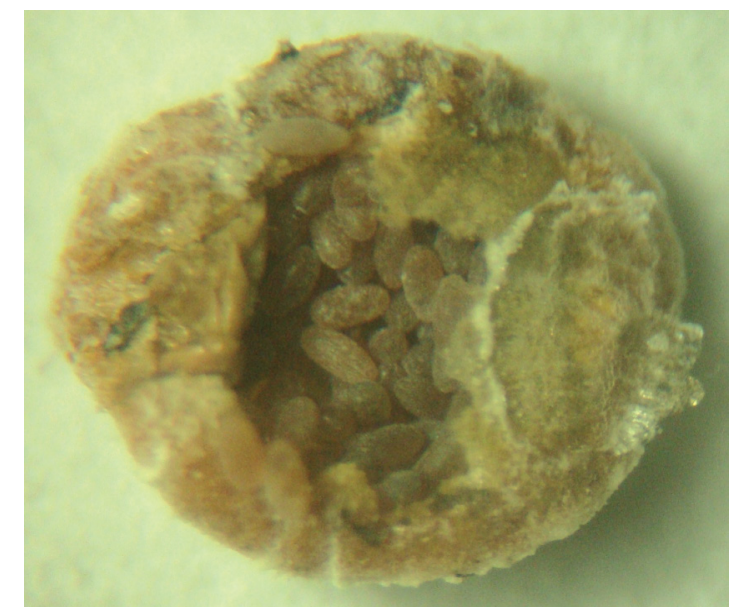

Figure 3. Eggs of L. dendrobii. Photo: Marsaro Júnior, A.L. 


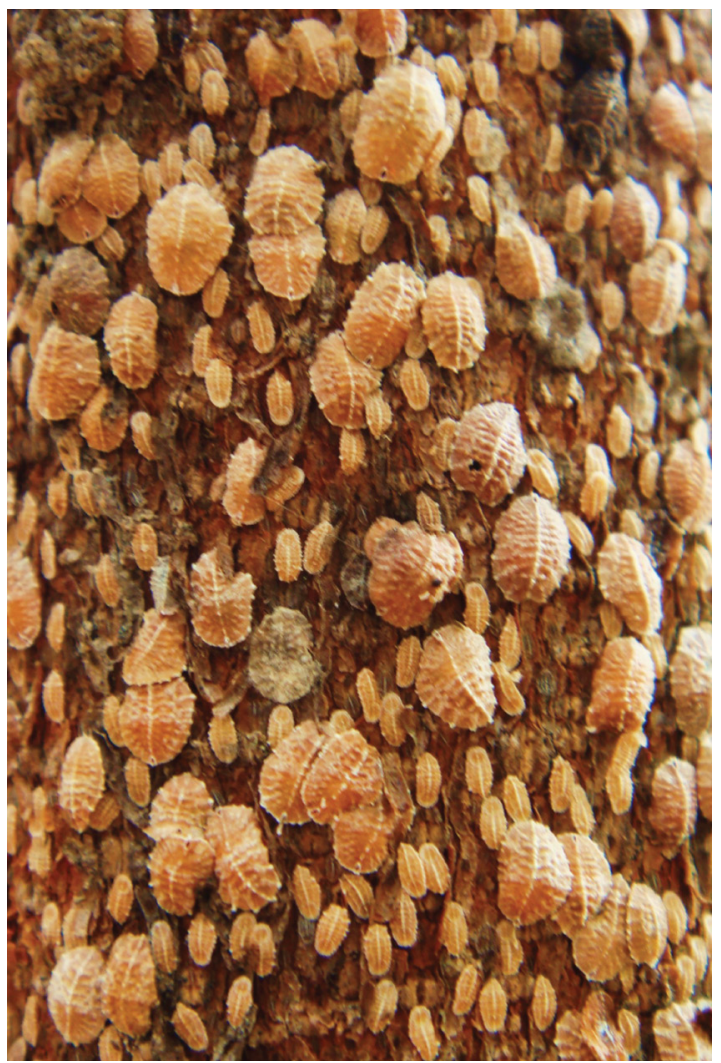

Figure 4. Colony of $L$. dendrobii in stem of $X$. aromatica. Photo: Marsaro Júnior, A.L.

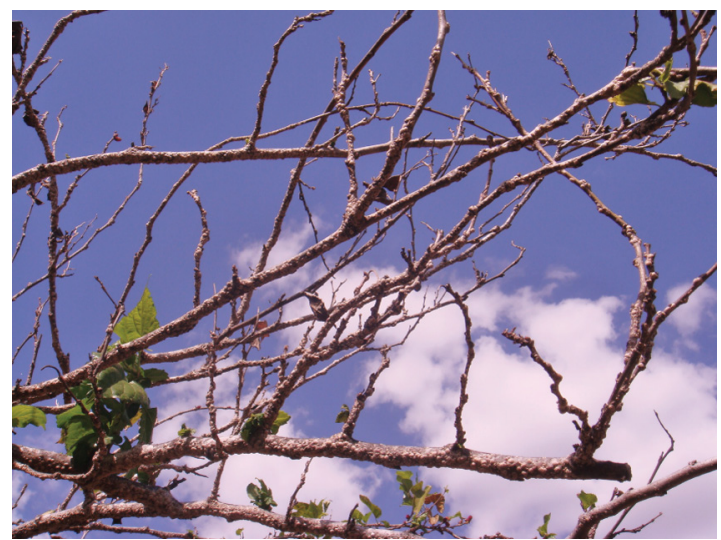

Figure 5. Drying of apical branches of $M$. nigra due to infestation of $L$. dendrobii. Photo: Marsaro Júnior, A.L.

At short distances, immature stages of these insects are easily transported by wind, water or animals, whereas the dispersion over long distances is done mainly through transport by the host plants. For monitoring of the distribution of $L$. dendrobii in Roraima and other states, visual inspection would be the best method and, the main measure to reduce the spread of this insect is to avert that plants or part of plants infested by lecanodiaspidids can be transported to places free of this insect.

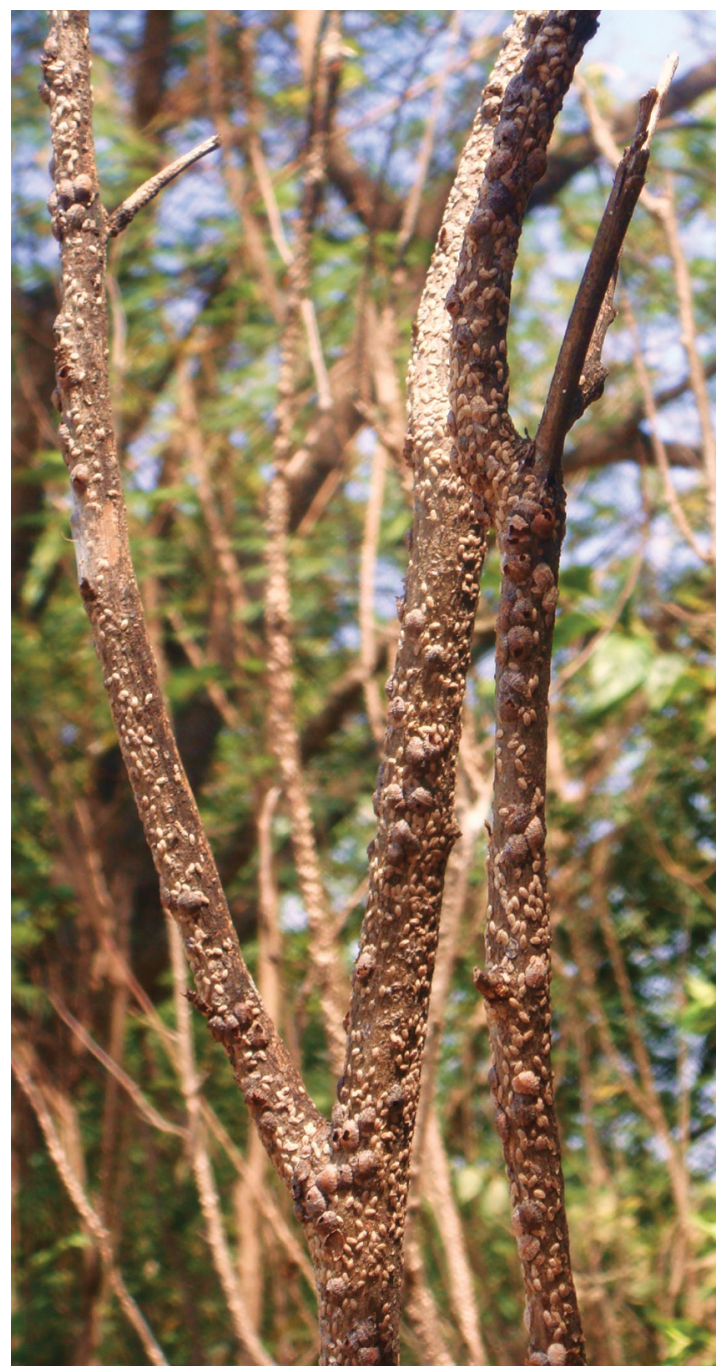

Figure 6. Death of young plant of $L$. leucophela due to infestation of $L$. dendrobii. Photo: Marsaro Júnior, A.L.

Although damage caused by L. dendrobii on their host plants has not been mentioned, Trelles (1938) reported that this pest was very abundant throughout Argentina, both in wild as cultivated plants, including Citrus spp. More recently, Granara de Willink and Claps (2003) made an inventory of scale insects associated to ornamental plants in Tucuman, Argentina, and they mentioned that L. dendrobii was not abundant on ornamental plants.

In Brazil, significant damage was recorded mainly on A. mangium, M. nigra and L. leucocephala. The injuries presented by these plants as partial or total plant dry is similar with those observed for some species of Diaspididae, differing from damage mentioned by Howell and Kosztarab (1972) to some members of Lecanodiaspididae that typically cause a depression in the host plant's tissues and often distortion of the shoots.

The natural enemies of $L$. dendrobii known until now are the gregarious endoparasitoids Anisophleps alternata Fidalgo, 1981 and Metaphycus terani Fidalgo, 1981 


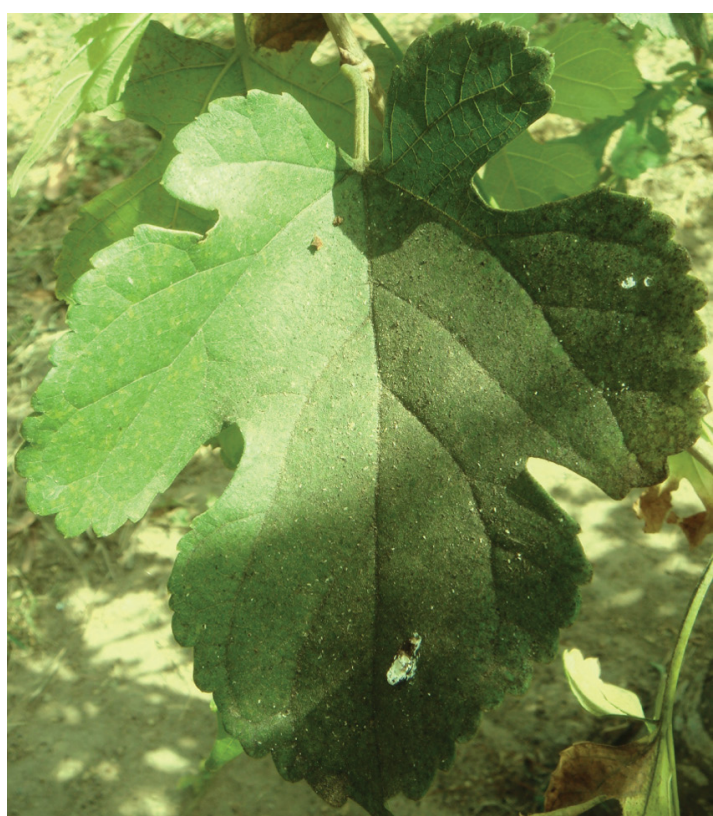

Figure 7. Sooty mold in leaf of M. nigra due to the honeydew excreted by L. dendrobii. Photo: Marsaro Júnior, A.L.

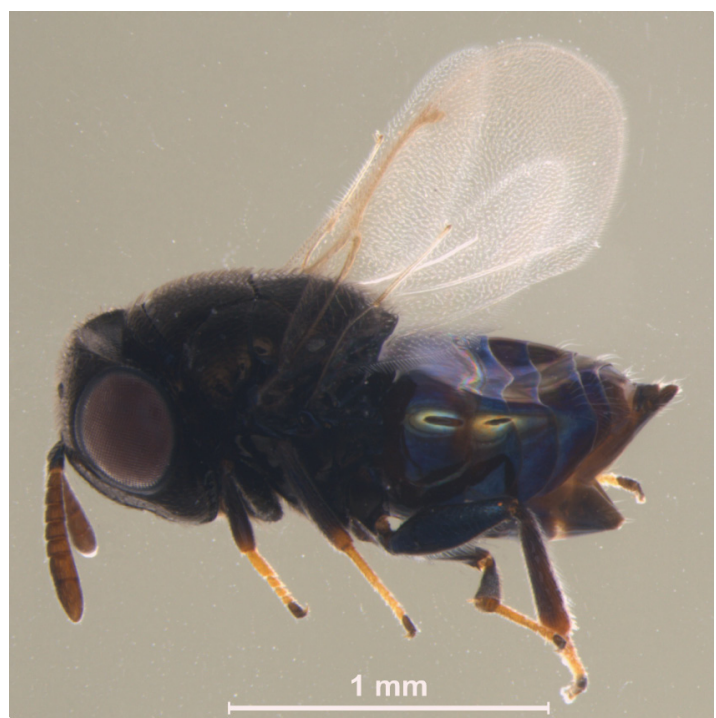

Figure 8. Adult female of Cephaleta sp., hymenopteran parasitoid associated with $L$. dendrobii. Photo: Costa, V.A.

(Hymenoptera: Encyrtidae), which have been observed on citrus in Tucuman, Argentina (Fidalgo, 1981). Blanchard (1938) also recorded the occurrence of a Signiphora species (Hymenoptera: Signiphoridae). Marietta caridei Brèthes, 1918 (Hymenoptera: Aphelinidae) has also been associated to L. dendrobii (De Santis, 1967), but, according to Hayat (1986), Marietta species are secondary parasitoids of Coccoidea. M. caridei, besides Argentina (Massini and Brèthes, 1918), also occurs in Brazil (Hayat, 1986) and Cuba (Hernandez and Ceballos, 1991 apud Noyes, 2014).

In Roraima state only the parasitoid Cephaleta sp. (Hymenoptera: Pteromalidae) was found in association with
L. dendrobii. Interactions between species of Cephaleta, Cephaleta australiensis (Howard, 1896), Cephaleta brasiliensis (De Santis, 1963) and Cephaleta brunniventris Motschulsky, 1859, with species of Asterolecaniidae, Cerococcidae, Coccidae, Eriococcidae and Pseudococcidae have been reported (Noyes, 2014), but with species of lecanodiaspidid is new.

This Cephaleta species is thought to be new because it differs from $C$. brasiliensis, the only specie of the genus known to occur in Brazil (De Santis, 1963), by the proportions of veins and absence of infumated area in the fore wings. Also, it differs from C. brunniventris and C. australiensis, which are the more widespread species of the genus, by the proportions of funicle segments and color of the gaster, in the case of $C$. brunniventris.

The potential of Cephaleta sp. in the biological control of $L$. dendrobii needs to be studied as well as the inventory of other potential predators and parasitoids.

Following the norms for the notification of the occurrence of exotic pest in the country, immediately after the confirmation of $L$. dendrobii in Boa Vista, Roraima, the Ministério da Agricultura, Pecuária e Abastecimento (MAPA) was communicated, according to IN 52 of the MAPA (Brasil, 2007), in order that preventive measures be taken to avert the spread of this pest for other Brazilian states.

Based on the observed damage in plants infested by L. dendrobii in the state of Roraima, this scale insect could become an important fruticulture and silviculture pest in Brazil, if biological control agents are not effective in controlling this exotic species.

\section{Acknowledgements}

We are grateful to Dr. Daniel Alejandro Aquino, Museo de La Plata/Universidad Nacional de La Plata, Buenos Aires, Argentina, for the help with the paratypes of Cephaleta brasiliensis; to the "Instituto Nacional de Ciência e Tecnologia dos Hymenoptera Parasitoides da Região Sudeste Brasileira", for financial support to one of the authors and to Dr. Takumasa Kondo (CORPOICA, Palmira, Colombia) for reviewing the manuscript.

\section{References}

BLANCHARD, E.E., 1938. Informaciones técnicas. Boletín Informativo de la Dirección de Sanidad Vegetal, vol. 1, pp. 25-32.

BOUČEK, Z. and HEYDON, S.L., 1997. Pteromalidae. In: G.A.P. GIBSON, J.T. HUBER, J.B. WOOLLEY, eds. Annotated keys to the genera of Nearctic Chalcidoidea (Hymenoptera). Ottawa: National Research Council of Canada. p. 541-692.

BRASIL. Ministério da Agricultura, Pecuária e Abastecimento - MAPA, 2007 [viewed 20 May 2013]. Instrução normativa $n^{\circ}$ 52, de 20 de novembro de 2007. Estabelece a lista de pragas quarentenárias ausentes (A1) e de pragas quarentenárias presentes (A2) para o Brasil e aprova os procedimentos para as suas atualizações [online]. Diário Oficial da República Federativa do Brasil, Brasília, 21 nov. Seção 1. Available from: 
http://sistemasweb.agricultura.gov.br/sislegis/action/detalhaAto. do? method $=$ detalharAtosArvore $\&$ tipo $=I N M \&$ numeroAto $=0000$ $0052 \&$ seqA to $=000 \&$ valor $A n o=2007 \&$ orgao $=$ MAPA $\& \operatorname{codTipo}=$ \&desItem $=\&$ desItemFim $=\#$

DE SANTIS, L., 1963. Un nuevo Eunotini de Brasil (Hymenoptera, Chalcidoidea). Revista Brasileira de Biologia, vol. 23, pp. 131-134.

DE SANTIS, L., 1967. Catálogo de los Himenópteros Argentinos de la Serie Parasitica, incluyendo Bethyloidea. La Plata: Comision de Investigacion Cientifica. 337 p.

DOUGLAS, J.W., 1892. Notes on some British and exotic Coccidae. Entomologist's Monthly Magazine, vol. 28, pp. 207-209.

FIDALGO, A.P., 1981. Sobre un nuevo genero y dos nuevas especies de Encirtidos (Hymenoptera: Chalcidoidea) parasitoides de Lecanodiaspis dendrobii Dougl. (Homoptera: Coccoidea) sobre citrus en Tucuman, Argentina. Acta Zoológica Lilloana, vol. 36 , pp. $40-42$.

GARCÍA, M., DENNO, B., MILLER, D.R., MILLER, G.L., BEN-DOV, Y. and HARDY, N.B., 2015. [viewed 06 December 2015]. ScaleNet: a literature-based model of scale insect biology and systematics. [online]. Available from: http://scalenet.info/

GRANARA DE WILLINK, M.C. and CLAPS, L.E., 2003. Cochinillas (Hemiptera: Coccoidea) presentes en plantas ornamentales de la Argentina. Neotropical Entomology, vol. 32, no. 4, pp. 625-637. http://dx.doi.org/10.1590/S1519-566X2003000400013.

GULLAN, P.J., 1984. A revision of the gall-forming coccoid genus Apiomorpha Rübsaamen (Homoptera: Eriococcidae:
Apiomorphinae). Australian Journal of Zoology. Supplementary Series, vol. 97, pp. 1-203. http://dx.doi.org/10.1071/AJZS097.

HAYAT, M., 1986. Notes on some species of Marietta (Hymenoptera: Aphelinidae), with a key to world species. Colemania, vol. 2, pp. 1-18.

HOWELL, J.O. and KOSZTARAB, M., 1972. Morphology and systematics of the adult females of the genus Lecanodiaspis (Homoptera: Coccoidea: Lecanodiaspididae). Research Division Bulletin Virginia Polytechnic Institute and State University, vol. 70, p. 1-248.

MASSINI, P.C. and BRÈTHES, J., 1918. Tres nuevas cochinillas argentinas y sus parásitos. Anales Sociedad Rural Argentina, vol. 52, no. 3, pp. $148-158$.

MILLER, D.R., RUNG, A., PARIKH, G., VENABLE, G., REDFORD, A.J., EVANS, G. and GILL, R.J., 2014. [viewed 27 May 2014]. Scale Insects Edition 2. Fort Collins: USDA APHIS PPQ Identification Technology Program (ITP) [online]. Available from: http://idtools.org/id/scales

NOYES, J.S., 2014 [viewed 22 August 2014]. Universal Chalcidoidea Database. World Wide Web electronic publication [online]. Available from: http://www.nhm.ac.uk/research-curation/ research/projects/chalcidoids/database

TRELLES, C.A.L., 1938. Cochinillas exóticas introducidas en la República Argentina y daños que causan. Jornadas Agronómicas y Veterinarias, p. 341-362. 